\title{
Penerapan Model Pembelajaran Kooperatif Tipe Conecting, Organizing, Reflecting, Extending (CORE) Untuk Meningkatkan Kemampuan Koneksi Matematis Siswa Pada Materi Kubus Dan Balok
}

\author{
Rika Wahyuni ${ }^{1}$, Mariyam ${ }^{2}$, Vinsensia Reda Astiva Kumang ${ }^{3}$ \\ Prodi Pendidikan Matematika, STKIP Singkawang, Indonesia \\ rikawahyuni142@gmail.com ${ }^{1}$, mariyam ${ }^{2}, 180488 @$ gmail.com Vinsensiareda2709@gmail.com ${ }^{3}$
}

Kata Kunci:

Kemampuan Koneksi Matematis, Kubus dan Balok

\begin{abstract}
ABSTRAK
Penelitian ini bertujuan; (1) Untuk mengetahui perbedaan peningkatan kemampuan koneksi matematis siswa yang mendapat pembelajaran matematika melalui Model Pembelajaran Kooperatif Tipe CORE dan yang mendapat model pembelajaran langsung pada kelas VIII SMP Negeri 8 Singkawang; (2) Untuk mengetahui aktivitas siswa ketika diterapkan Model Pembelajaran Kooperatif Tipe CORE; (3) Untuk mengetahui motivasi siswa terhadap pembelajaran matematika dengan menggunakan Model Pembelajaran Kooperatif Tipe CORE. Jenis penelitian ini adalah Semu (Quasi Experimental)dengan desain penelitian Nonequivalent Control Group Design. Instrumen yang digunakan dalam penelitian ini adalah tes kemampuan koneksi matematis, lembar pengamatan aktivitas, lembar angket motivasi. Hasil analisis data menunjukkan bahwa: (1) Terdapat perbedaan peningkatan kemampuan koneksi matematis siswa antara yang menggunakan Model Pembelajaran Kooperatif Tipe CORE dan yang menggunakan model pembelajaran langsung. Hal ini dibuktikan dengan uji-t dua sampel independen. Maka diperoleh bahwa $t_{\text {hitung }}>t_{\text {tabel yaitu 6,17> 1,67 (2) Aktivitas siswa }}$ tergolong aktif saat diterapkan Model Pembelajaran Kooperatif Tipe CORE terhadap kemampuan koneksi matematis dengan persentase aktivitas siswa sebesar 81,59\%; (3) Motivasi siswa tinggi saat diterapkan Model Pembelajaran Kooperatif Tipe CORE terhadap kemampuan koneksi matematis siswa dengan perolehan skor sebesar 3,9.
\end{abstract}




\section{PENDAHULUAN}

Pembelajaran Matematika yang dirumuskan oleh National Council of mathematics (NCTM) secara umum menggariskan, bahwa siswa harus mempelajari matematika melalui pemahaman dan aktif membangun pengetahuan baru dari pengalaman dan pengetahuan yang telah dimiliki sebelumnya (NCTM, 2000).Menurut NCTM, (2000:29), ada lima standar proses dalam pembelajaran matematika, yaitu belajar untuk memecahkan masalah (mathematical problem solving), belajar untuk bernalar dan bukti (mathematical reasoning and proof), belajar untuk berkomunikasi (mathematical communication), belajar untuk mengaitkan ide (mathematical connections), dan belajar untuk mempresentasikan (mathematics representation). Satu di antara kelima standar proses pembelajaran tersebut yaitu kemampuan koneksi matematis (mathematical connections). Dalam pembelajaran matematika, kemampuan koneksi matematis merupakan kemampuan mengaitkan antar topik dalam matematika, mengaitkan matematika dengan ilmu lain, dan mengaitkan matematika dengan kehidupan sehari-hari (NCTM, 2000:64). Ini mengindikasikan jika kemampuan koneksi matematika tidak dikuasai dengan baik, maka akan berpengaruh terhadap hasil belajar siswa.

Berdasarkan beberapa pengertian kemampuan koneksi diatas dengan beberapa indikator maka dapat disimpulkan bahwa indikator yang diambil yaitu berdasarkan Nurfauziah ( Nurainah 2018). Tetapi pada kenyataanya kemampuan koneksi matematis siswa masih sangat rendah. Berdasarkan penelitian yang dilakukan oleh Nola Nari, dkk ( Nurainah 2018) ditemukan bahwa kemampuan koneksi matematis dalam pembelajaran masih rendah, karena dalam proses pembelajaran siswa tidak mampu mengaitkan materi sebelumnya dengan konsep matematika yang akan dipelajari. Kemudian pada Penelitian Sholekah, dkk(2017) mengemukakan bahwa masih banyak siswa yang mengalami kesulitan dalam menyelesaikan soal kemampuan koneksi matematis sehingga prestasi siswa rendah. Selain itu Warih,dkk(2016) juga menyatakan bahwa kemampuan koneksi matematis siswa di Sekolah masih sangat rendah dikarenakan siswa masih belum mampu dalam melakukan pengoneksian secara maksimal.Hal ini juga dibuktikan dari hasil penelitian Ruspiani (2000:46) bahwa kemampuan koneksi matematis siswa pada salah satu sekolah menengah di Medan tergolong rendah, nilai rataratanya kurang dari 60 pada skor 100 , yaitu $22,2 \%$ untuk koneksi matematis siswa dengan topik disiplin ilmu lain, 44,9\% untuk koneksi matematis dengan topik di dalam matematika, dan 67,3\% untuk aspek koneksi matematis siswa dengan kehidupan sehari-hari. Penelitian Ruspiani tersebut menunjukkan bahwa masih rendahnya kemampuan koneksi matematis siswa pada siswa kelas menengah. Hal ini juga serupa dengan hasil penelitian yang dilakukan oleh Saputra, dkk (2019) Berdasarkan hasil observasi di SMP Negeri 15 Kota Jambi untuk kelas VIII dalam proses pembelajaran dikelas dengan salah satu guru matematika mengatakan bahwa kemampuan koneksi matematis siswa masih rendah. Hal yang serupa juga terjadi pada siswa kelas VIII SMP Negeri 8 Singkawang yang kemampuan koneksi matematis siswa masih belum baik. Siswa masih belum mampu mengaitkan konsep-konsep yang telah mereka pelajari sebelumnya dalam pemecahan masalah yang berkaitan dengan topik pelajaran. Rendahnya kemampuan koneksi matematis siswa kelas VIII SMP Negeri 8 Singkawang, dibuktikan dengan hasil pra-riset dilakukan peneliti di SMP Negeri 8 Singkawang dengan memberikan soal yang memuat indikator kemampuan koneksi matematis pada materi persegi di kelas VIII. Peneliti memberikan 3 soal dengan 3 indikator kemampuan koneksi matematis, yaitu: (1) memahami hubungan antar topik matematika; (2) memahami hubungan antar topik matematika dengan ilmu lain; (3) memahami hubungan antar topik matematika dengan kehidupan sehari-hari. Soal diberikan kepada 30 orang siswa dan hasilnya menunjukkan bahwa kemampuan koneksi matematis siswa masih rendah. Adapun hasil pra riset tersebut ditunjukkan pada gambar 1 . berikut ini. 


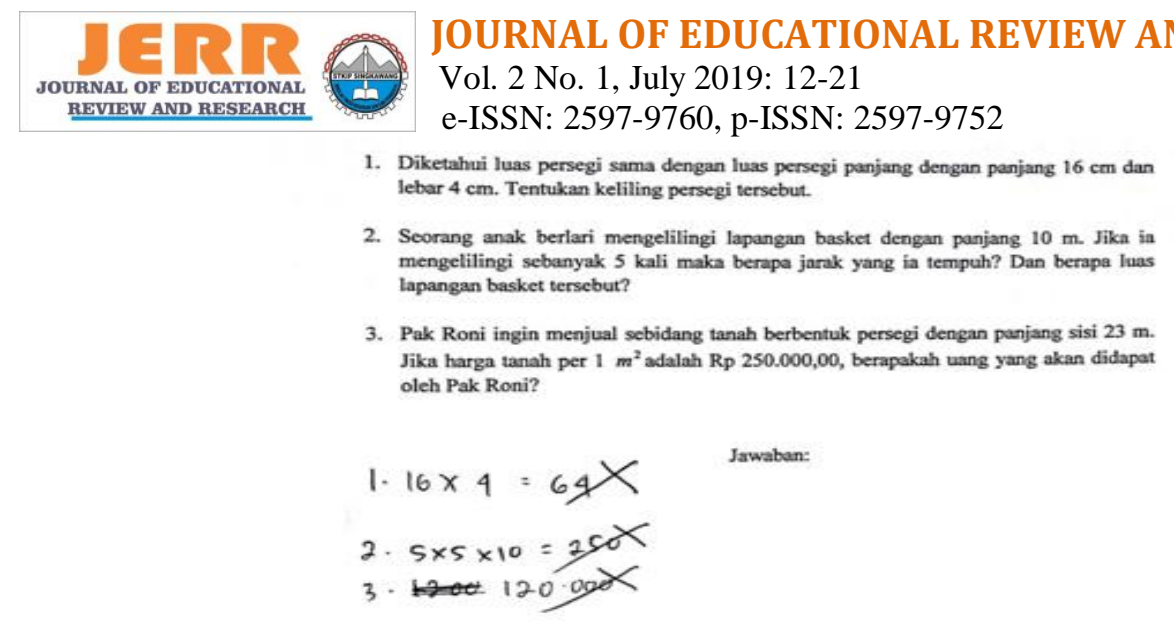

\section{Gambar 1. Hasil Pra riset}

Berdasarkan hasil keseluruhan pra riset yang diberikan, maka dapat disimpulkan sebagai berikut: (1) Pada indikator pertama (keterkaitan dalam topik matematika) terdapat 7 siswa yang dapat menjawab pertanyaan dengan benar dan 23 orang siswa yang menjawab pertanyaan salah; (2) Pada indikator kedua (keterkaitan dengan disiplin ilmu lain) terdapat 3 orang siswa yang dapat menjawab pertanyaan dengan benar dan 27 orang siswa yang menjawab pertanyaan salah; (3) Pada indikator ketiga (keterkaitan dengan kehidupan sehari-hari) terdapat 10 siswa yang dapat menjawab dengan benar dan 20 siswa menjawab pertanyaan salah. Dari hasil keseluruhan pra riset yang telah dilakukan, terbukti bahwa kemampuan koneksi matematis siswa di SMP Negeri 8 Singkawang masih rendah maka dari itu harus ditingkatkan. Dari hal tersebut, maka penulis akan melakukan observasi pada siswa kelas VIII SMP Negeri 8 Singkawang untuk mengetahui masalah apa saja yang terjadi pada siswa yang mengakibatkan kemampuan koneksi matematis siswa rendah. Ruspiani(Mandur, dkk 2013) menyatakan kemampuan siswa dalam melakukan koneksi matematis masih rendah terutama untuk koneksi antar topik matematika. Begitu pula dengan hasil penelitian Agustianti(Fajri,2018) yang menyatakan bahwa tingkat kemampuan koneksi matematis siswa SMP masih rendah. Hasil penelitian tersebut menunjukkan bahwa jumlah siswa yang memiliki kemampuan koneksi masih rendah. Selain itu berdasarkan observasi yang dilakukan peneliti ketika berada di kelas diperoleh bahwa aktivitas belajar siswa masih rendah. Banyak siswa merasa bingung dan tidak mengerti dalam mengerjakan soal cerita yang berkaitan dengan kehidupan sehari - hari ketika guru memberikan sebuah permasalahan atau topik yang diberikan sehingga siswa menjadi kurang aktif untuk mengikuti pelajaran matematika. Selain itu, ditemukan bahwa masih terdapat siswa yang melalaikan tugas rumah (PR) dan siswa belum terlibat aktif dalam kegiatan pembelajaran matematika.Padahal belajar tidak efektif kalau tidak ada aktivitas siswa karena aktivitas merupakan prinsip atau asas yang sangat penting didalam interaksi belajar mengajar Sardiman, A.M. (2016:96).Rendahnya kemampuan koneksi matematis siswa akan mempengaruhi kualitas belajar siswa dan berdampak pada rendahnya prestasi siswa di Sekolah. Selanjutnya melatih siswa dalam menjelaskan keterkaitan antar konsep dan mengaplikasikan konsep atau algoritma, secara luwes akurat efisien dan tepat dalam pemecahan masalah bukanlah hal yang mudah bagi seorang guru. Suatu upaya guru untuk meningkatkan kemampuan koneksi matematis siswa dapat digunakan berbagai macam strategi, metode, model ataupun teknik pembelajaran. Ruseffendi (Trihandayani, 2012:9) mengemukakan bahwa dengan menggunakan teknik atau metode mengajar, kemungkinan siswa akan lebih aktif belajar karena sesuai dengan gaya belajar siswa, dapat meningkatkan semangat dan lain-lain. Dengan demikian, perlu adanya sebuah model pembelajaran yang dapat meningkatkan kemampuan koneksi matematis siswa yang didalamnya terdapat aktivitas menghubungkan, mengorganisasikan, memikirkan kembali, dan memperluas wawasan. Oleh karena itu, peneliti mencoba menggunakan model pembelajaran kooperatif tipe CORE(Connecting, Organizing, Reflecting, Extending).

Model pembelajaran kooperatif tipe CORE merupakan satu diantara model pembelajaran dengan metode diskusi. Model pembelajaran kooperatif tipe CORE mencakup empat proses, yaitu Connecting Organizing Reflecting Extending (Calfee et. al, dalam Jacob, 2005: 13). Dalam Connecting, siswa diajak untuk dapat menghubungkan pengetahuan baru dengan pengetahuannya lama pada tahap ini erat kaitan dengan indikator koneksi yaitu pada indikator hubungan antar topik matematika. 
Organizing, membantu siswa untuk dapat mengorganisasikan pengetahuannya. Reflecting, siswa dilatih untuk dapat menjelaskan kembali informasi yang telah mereka dapatkan. Terakhir yaitu Extending atau proses memperluas pengetahuan siswa, satu diantaranya dengan jalan diskusi.Dengan diterapkannya model pembelajaran kooperatif tipe CORE diharapkan dapat menjembatani siswa untuk menggunakan dan menilai keterkaitan antar topik matematika dan keterkaitan topik di luar matematika, dan menggunakan matematika dalam kehidupan sehari-hari, sehingga dapat mempengaruhi kemampuan koneksi matematis siswa. Pada teori Piaget erat kaitannya dengan connecting dimana dalam teori piaget asimilasi merupakan proses pengintegrasian atau penyatuan informasi baru ke dalam struktur kognitif yang telah dimiliki oleh individu. Kemudian pada teori Vygotsky menekankan pada aspek sosial sehingga Implementasi dari teori Vygotsky pada model pembelajaran kooperatif tipe CORE adalah pada kegiatan diskusi dimana kelompok perlu dirancang oleh guru agar terbentuk kelompok dengan kemampuan anggota yang heterogen dan siswa berdiskusi menggunakan pengetahuannya untuk memahami suatu materi. Rokhaeni.A,dkk (2015:5) menyatakan bahwa peningkatan kemampuan koneksi matematis siswa yang mendapatkan pembelajaran menggunakan model CORE lebih baik dari pada siswa yang mendapat pembelajaran menggunakan model ekspositori. Hal ini juga dibuktikan dari penelitian yang dilakukan Agustianti, dkk (2018:4)bahwa kemampuan koneksi matematis siswa dengan diterapkannya model pembelajaran CORE(Connecting, Organizing, Reflecting, Extending)lebih baik dari pada kemampuan koneksi siswa sebelum diterapkannya model pembelajaran tersebut. Kemampuan koneksi matematis baik karena diterapkan model kooperatif tipe CORE, model pembelajaran ini adalah suatu model yang dapat mengaktifkan siswa, dan dengan adanya model ini siswa dapat termotivasi, serta dapat meningkatkan koneksi matematis siswa baik itu antar topik matematika dengan ilmu matematika, antar topik matematika dengan ilmu lain atau dengan kehidupan sehari- hari.

\section{METODE}

Jenis penelitian yang digunakan ini adalah penelitian kuantitatif. Desain penelitian ini adalah Semu (Quasi Experimental)dengan rancangan penelitian yang digunakan berbentuk Nonequivalent Control Group Design. Desain Nonequivalent Control Group Design ini kelompok eksperimen maupun kelompok kontrol tidak dipilih secara random Sugiyono (2017:79).Adapun populasi dalam penelitian ini Populasi dalam penelitian ini adalah seluruh siswa kelas VIII SMP Negeri 08 Singkawang yaitu VIIIA, VIII B, VIII C, VIII D, VIII E, dan VIII F.Teknik yang digunakan untuk mengambil sampel pada penelitian ini adalah teknik Purposive sampling. Adapun yang menjadi kelas eksperimen adalah kelas VIII B dan kelas kontrol adalah kelas VIII A.Teknik pengumpulan data yang dimaksud dalam penelitian ini adalah lembar tes kemampuan koneksi matematis. Lembar tes yang digunakan yaitu berupa lembar tes awal (Pre-test)dan akhir (Post-test) yang terdiri dari masing- masing enam butir soal. Selain lembar tes, instrumen yang digunakan dalam penelitian ini adalah lembar pengamatan aktivitas digunakan untuk melihat keterlibatan siswa dalam proses pembelajaran. Angket digunakan untuk mengetahui motivasi belajar siswa dengan menggunakan lembar angket motivasi belajar siswa yang terdiri dari 22 pernyataan dengan memberi tanda ceklis $(\sqrt{ })$.

Instrumen pengumpulan data yang dimaksud dalam penelitian ini berupa soal tes kemampuan koneksi matematis, lembar pengamatan, dan lembar angket. Instrumen pengumpulan data berupa tes terlebih dulu di uji validitas, reliabilitas, daya pembeda dan tingkat kesukarannya.Validitas bertujuan agar tes yang digunakan benar-benar untuk mengukur kemampuan siswa dalam menyelesaikan soal kubus dan balok, maka instrumen yang telah disusun diukur dengan validitas tes. Dari hasil perhitungan ketiga validator dengan aspek yang dinilai validitas RPP 1, validitas RPP 2, soal pretest, soal posttest, lembar aktivitas, dan angket motivasi diperoleh kriterianya sangat valid. Berdasarkan analisis validasi soal uji coba maka diketahui soal 1,2,3,4 dan 5 berada pada kriteria tinggi, sedangkan soal nomor 6 berada pada kriteria sangat tinggi, maka soal tersebut layak untuk digunakan sebagai instrumen penelitian. Reliabilitas dikatakan baik jika kriteria memenuhi reliabilitas tinggi dan sangat tinggi, karena menurut Siregar (2013: 57) menyatakan bahwa kriteria suatu instrumen penelitian dikatakan reliabel bila koefisien reliabilitas $\left(r_{11}\right)>0,6$. Berdasarkan hasil uji coba soal yang dilakukan peneliti di SMP 
Negeri 20 Singkawang dengan jumlah siswa 27 orang, secara keseluruhan tes kemampuan koneksi matematis siswa diperoleh nilai tingkat reliabilitas sebesar 0,72. Maka dapat diinterpretasikan bahwa soal tes kemampuan koneksi matematis siswa mempunyai reliabilitas tinggi dan layak digunakan. Untuk indeks kesukaran soal tes kemampuan koneksi matematis siswa yang terdiri dari 6 soal, menunjukan soal tes kemampuan koneksi matematis siswa memiliki indeks kesukaran sedang. Maka soal tersebut layak untuk digunakan. Adapun hasil perhitungan daya dapat dilihat bahwa soal tes kemampuan koneksi matematis siswa yang terdiri dari 6 soal, maka secara keseluruhan soal tes kemampuan koneksi matematis siswa mempunyai memiliki daya pembeda 0,25 dengan kriteria cukup dan layak dipakai sebagai acuan untuk membedakan antara siswa yang pandai (berkemampuan tinggi) dengan siswa yang kurang pandai (berkemampuan rendah), Sehingga secara keseluruhan soal dapat digunakan untuk penelitian. Adapun rekapitulasi hasil uji coba soal kemampuan koneksi matematis siswa setelah diuji validitas, reliabilitas, indeks kesukaran, dan daya pembeda maka dapat disimpulkan bahwa soal tersebut layak dipakai sebagai acuan untuk mengukur kemampuan koneksi matematis siswa.

\section{HASIL DAN PEMBAHASAN}

Berdasarkan hasil pengumpulan data selama penelitian diperoleh data hasil skor pretest dan posttest dari kelas yang diajarkan dengan model pembelajaran kooperatif tipe CORE untuk kelas eksperimen dan pembelajaran langsung untuk kelas kontrol terhadap kemampuan koneksi matematis siswa pada materi kubus dan balok. Penilaian kemampuan koneksi matematis siswa dinilai dari skor rata-rata tiap indikator kemampuan koneksi matematis siswa dan nilai rata-rata kemampuan koneksi matematis siswa. Indikator dari dalam penelitian ini antara lain: (a) Memahami hubungan antar topik matematika dengan matematika dengan skor 4, (b) Memahami hubungan antar topik matematika dengan ilmu bidang lain skor 4, (c) Memahami hubungan antar topik matematika dengan kehidupan sehari- hari dengan skor 4. Dimana di setiap indikator tersebut masing- masing terdiri dari 2 buah soal essay dengan skor total 24. Berdasarkan analisis hasil posttest kemampuan pemahaman konsep matematis siswa pada kelas kontrol dan eksperimen rata-rata skor untuk setiap indikator kemampuan koneksi matematis siswa dapat dilihat pada Gambar 2. Berdasarkan hasil tes pretest dan posttest pada kelas eksperimen dan kelas kontrol dapat digambarkan dengan diagram batang seperti pada gambar 2 sebagai berikut.

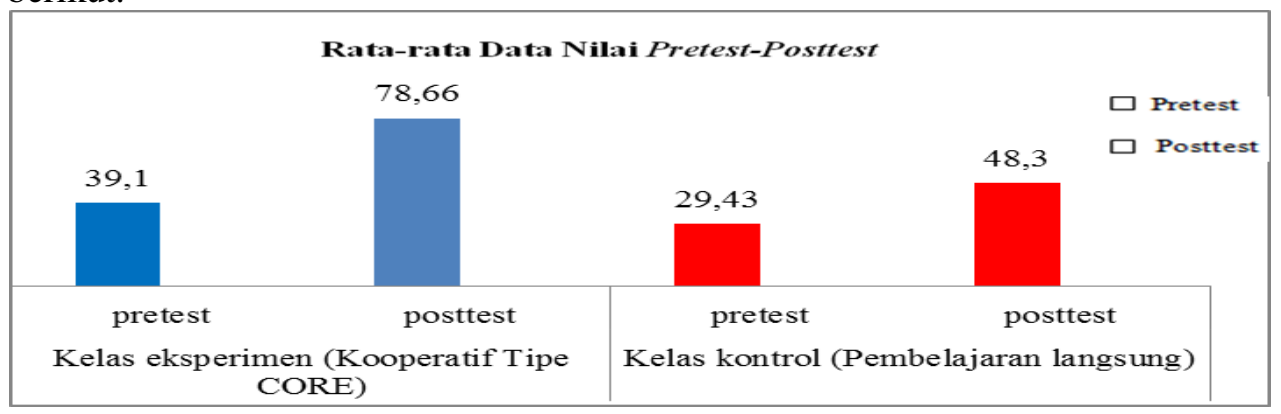

\section{Gambar 2. Diagram Batang Kelas Eksperimen dan Kelas Kontrol}

Berdasarkan Gambar 2 dapat diketahui bahwa pada kelas eksperimen maupun kelas kontrol nilai posttest selalu lebih tinggi dibandingkan nilai prettestnya.Hal ini menunjukkan adanya peningkatan.selanjutnya jika dibandingkan antara kelas eksperimen dan kelas kontrol, nilai posttest di kelas eksperimen lebih tinggi dibandingkan kelas kontrol. Secara keseluruhan dapat disimpulkan bahwa kemampuan koneksi matematis siswa antara kelas eksperimen dan kelas kontrol berbeda.Selain itu, berdasarkan uji hipotesis menunjukkan bahwa Ho ditolak dan Ha diterima sehingga terdapat perbedaan yang signifikan antara kelas eksperimen yang menggunakan model pembelajaran kooperatif tipeCORE dan kelas kontrol yang menggunakan model pembelajaran langsung yaitu kemampuan koneksi matematis siswa kelas eksperimen lebih tinggi dibanding kemampuan koneksi matematis siswa kelas kontrol. Hal ini dikarenakan pembelajaran matematika dengan menggunakan model 
pembelajaran kooperatif tipe CORE lebih efektif daripada pembelajaran matematika dengan menggunakan model pembelajaran langsung. Perbedaan kemampuan koneksi matematis siswa disebabkan karena adanya perbedaan yang ditimbulkan oleh masing-masing perlakuan terhadap kemampuan koneksi matematis siswa.

Model pembelajaran kooperatif tipe CORE mempunyai pengaruh yang baik pada kemampuan koneksi matematis siswa dilihat dari hubungan antara langkah model CORE dengan indikator koneksi matematis, pada tahap Connecting pada tahap ini siswa diminta untuk menghubungkan pengetahuan yang telah lalu dengan pelajaran yang akan datang baik itu antar topik matematika dengan topik matematika, antar topik matematika dengan ilmu lain atau dengan kehidupan sehari- hari, kemudian tahap Organizing dengan pengetahuan yang telah mereka peroleh siswa diminta dalam kelompok untuk mengorganisasikan soal atau pengetahuan yang telah yang telah mereka peroleh baik itu antar topik matematika dengan topik matematika, antar topik matematika dengan ilmu lain atau dengan kehidupan sehari- hari, kemudian pada tahap Reflecting erat kaitan dengan indikator koneksi pada tahap ini siswa diuji kembali pemahamannya baik itu antar topik matematika dengan topik matematika, antar topik matematika dengan ilmu lain atau dengan kehidupan sehari- hari guna untuk melihat sejauh mana pemahaman siswa tersebut. Extending tahap memperluas pengetahuan siswa dengan memberikan soal lain baik itu antar topik matematika dengan topik matematika, antar topik matematika dengan ilmu lain atau dengan kehidupan sehari- hari maka dari itu kemampuan koneksi matematis dengan adanya model CORE menjadi baik selain itu motivasi beljar siswa juga meningkat dgn adanya model dan tidak membuat siswa bosan serta siswa lebih aktif dengan model CORE ini. Hal ini juga sejalan dengan hasil penelitian Wahyuningsih (2017) Kemampuan koneksi matematis siswa juga meningkat dengan adanya model pembelajaran kooperatif tipe CORE, ditunjukkan dengan siswa dapat memahami hubungan di antara konsep matematika, memahami keterkaitan ide-ide matematika dan membentuk ide satu dengan yang lain, menerapkan matematika dalam kehidupan sehari-hari. Khaulah (2019) Peningkatan kemampuan koneksi matematika siswa yang diajarkan dengan model pembelajaran CORE(Connecting,Organizing, Reflecting, Extending) lebih baik dari pada siswa yang diajarkan dengan model pembelajaran konvensional. Dari beberapa keterkaitan antara indikator kemampuan koneksi matematis dan model pembelajaran kooperatif tipe CORE serta diperkuat dari hasil penelitian beberapa peneliti maka diharapkan dengan menerapkan model pembelajaran kooperatif tipe CORE ini kemampuan koneksi matematis siswa, aktivitas dan motivasi belajar siswa dapat meningkat.

Siswa yang diberi perlakuan dengan menggunakan model pembelajaran kooperatif tipe CORE mendapat kontribusi lebih baik daripada siswa yang diberi perlakuan dengan pembelajaran langsung. Hal ini sejalan dengan penelitian yang dilakukan oleh Rokhaeni, dkk (2011) dapat ditarik beberapa kesimpulan bahwa kemampuan koneksi matematis siswa yang mendapatkan pembelajaran menggunakan model pembelajaran kooperatif tipe CORE lebih baik dari pada siswa yang mendapat pembelajaran secara konvensional.

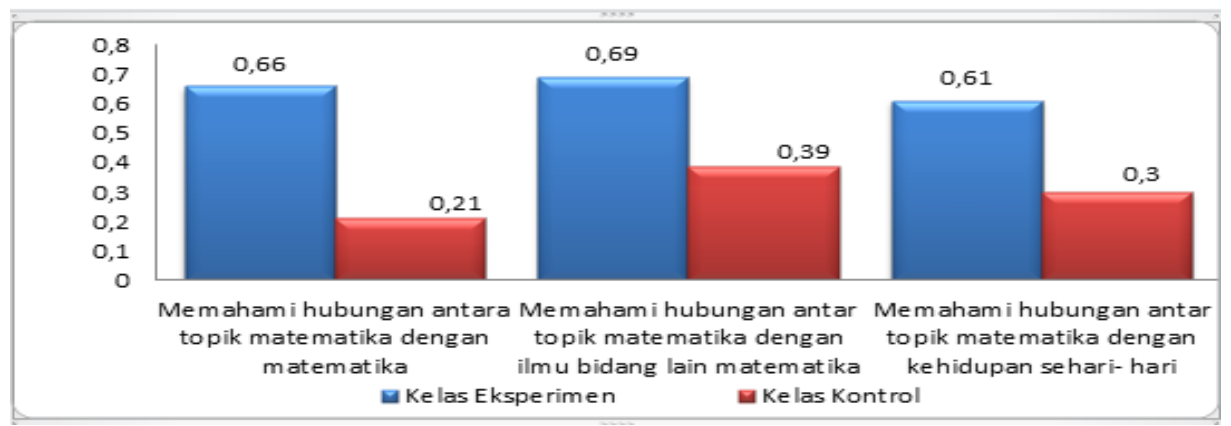

Gambar 3. Diagram Batang Nilai Rata-Rata $N$-gain Kelas Eksperimen Dan Kelas Kontrol Berdasarkan Kemampuan Koneksi Matematis. 
Dari Gambar 3 dapat diketahui bahwa peningkatan kemampuan koneksi matematis siswa pada kelas eksperimen nilai $\mathrm{N}$-gain selalu lebih tinggi dari pada nilai $\mathrm{N}$-gain kelas kontrol dari setiap indikator dan indikator paling tinggi terletak pada indikator kedua. Dapat dikatakan bahwa peningkatan kemampuan koneksi matematis siswa pada kelas yang menggunakan model Kooperatif tipe CORE lebih tinggi dari kelas yang menggunakan model pembelajaran langsung. Maka selanjutnya untuk mengetahui perbedaan peningkatan kemampuan koneksi matematis perhitungan selanjutnya menggunakan uji-t dua sampel independen. Untuk melihat perbedaan peningkatan kemampuan koneksi matematis antara kelas yang menggunakan model kooperatif tipe CORE (kelas eksperimen) dan kelas yang menggunakan pembelajaran langsung (kelas kontrol) maka menggunakan uji-t dua sampel independen. Sebelum uji-t dua sampel independen digunakan maka terlebih dahulu menggunakan uji normalitas dan selanjutnya uji homogenitas.Diperoleh bahwa data $N$-gain pada kelas eksperimen $x_{\text {hitung }}^{2} \leq x_{\text {tabel }}^{2}$ yaitu $10,3646 \leq 11.070$. Sedangkan data $N$-gain pada kelas kontrol $x_{\text {hitung }}^{2} \leq x_{\text {tabel }}^{2}$ yaitu $6,871 \leq 1107$, yang artinya $\mathrm{H}_{\mathrm{o}}$ diterima dan $\mathrm{H}_{\mathrm{a}}$ ditolak hal ini dapat disimpulkan bahwa data $\mathrm{N}$-gain pada kelas eksperimen dan kelas kontrol adalah berdistribusi normal.Setelah kedua sampel penelitian tersebut dinyatakan berdistribusi normal maka selanjutnya dicari nilai homogenitas dengan menggunakan uji varians. Dari hasil perhitungan homogenitas nilai $N$ gain dengan menggunakan uji homogenitas variansi diperoleh $f_{\text {hitung }} \leq f_{\text {tabel }}$ yaitu $4,00<5,05$. Dengan demikian dapat disimpulkan bahwa nilai N-gain dari kedua varians dari kelompok eksperimen dan kelompok kontrol adalah homogen. Berdasarkan uji normalitas dan uji homogenitas diperoleh bahwa data $\mathrm{N}$-Gain kelas eksperimen maupun kelas kontrol berdistribusi normal dan mempunyai varians yang sama (homogen). Maka untuk menguji kesamaan rata-rata kedua kelas selanjutnya dapat digunakan dengan menggunakan uji-t dua sampel independen. Berdasarkan hasil perhitungan uji-t dua sampel independen. diperoleh bahwa $t_{\text {hitung }}>t_{\text {tabel }}$ yaitu 6,17 $>1,67$. Dengan demikian Ho ditolak dan Ha diterima dengan taraf signifikan 5\% atau 0,05 sehingga dapat disimpulkan bahwa terdapat perbedaan peningkatan yang signifikan antara kelas eksperimen dan kelas kontrol yaitu kemampuan koneksi matematis siswa kelas kelas eksperimen lebih tinggi dibanding kemampuan koneksi matematis siswa kelas kontrol.Berdasarkan perhitungan data aktivitas pada lembar pengamatan Aktivitas siswa terhadap model pembelajaran kooperatif tipe CORE pada materi kubus dan balok di kelas SMP Negeri 8 Singkawang diperoleh rata-rata aktivitas siswa sebesar 81,59\%, dengan kategori sangat aktif. Analisis data tersebut maka persentase aktivitas siswa dapat dilihat pada gambar 4 berikut.

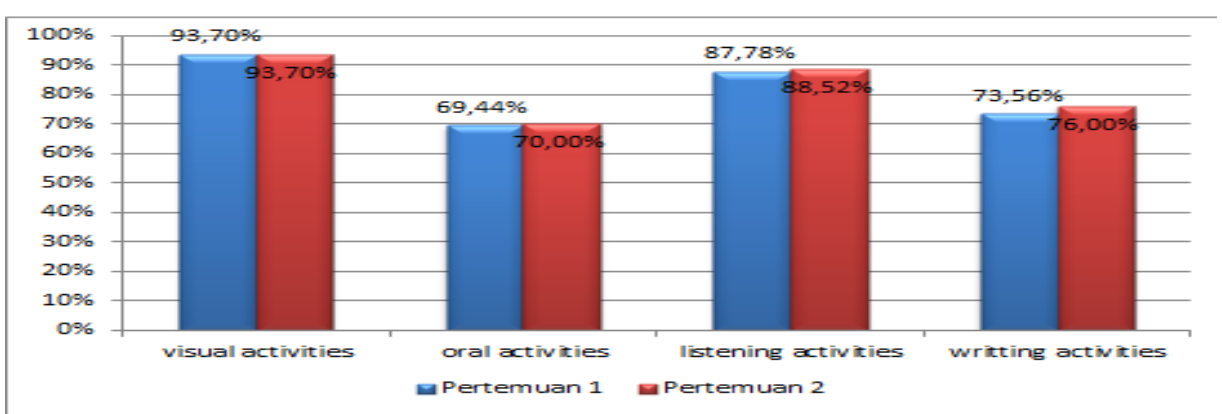

Gambar 4. Diagram Batang Persentase Aktivitas Siswa tiap Indikator

Dari gambar 4 dapat dilihat bahwa setiap indikator aktivitas siswa mengalami peningkatan dari pertemuan pertama ke pertemuan dua, kecuali pada indikator visual activities pada pertemuan pertama dan kedua berada pada posisi yang sama hal ini disebabkan karena pada pertemuan pertama maupun pertemuan yang kedua visual activities yang diberikan sama, dan dari keempat indikator aktivitas yang diberikan visual activities peningkatannya lebih tinggi diantara keempat indikator aktivitas tersebut. Dengan demikian dapat disimpulkan bahwa siswa menjadi sangat aktif pada pembelajaran materi kubus dan balok yang diberikan perlakuan dengan menggunakan model pembelajaran kooperatif tipe CORE. Penerapan pembelajaran dengan model CORE dapat membuat siswa menjadi sangat aktiv semua langkah pada model pembelajaran CORE menuntut keaktivan siswa terbukti dengan model ini siswa sangat aktif pada tahap Connecting pada tahap ini siswa diminta untuk 
menghubungkan pengetahuan yang telah lalu dengan pelajaran yang akan datang baik itu dengan membaca, atau memperhatikan gambar atau visual activities, kemudian tahap Organizing dengan pengetahuan yang telah mereka peroleh siswa diminta dalam kelompok untuk mengorganisasikan soal atau pengetahuan yang telah yang telah mereka peroleh tahap ini siswa diharapkan untuk mengeluarkan pendapat atau oral activities, tahap ini juga sangat membutuhkan keaktifan siswa dari membentuk sebuah kelompok hingga mendapatkan jawaban pada tahap ini tahapannya berkaitan deng, kemudian pada tahap Reflecting pada tahap ini siswa diuji kembali pemahamannya pada tahap ini juga sangat dibutuhkan keaktifan siswa dalam berfikir dan menyelesaikan soal tahap ini siswa melakukan percobaan visual activities dalam memecahkan masalah., kemudian tahap akhir Extending atau memperluas pengetahuan siswa dengan member soal untuk melihat sejauh mana pengetahuan siswa tentang pelajaran yang telah dipelajari padatahap ini juga sangat dibutuhkan keaktivan siswa dalam melakukan percobaan visual activities, siswa juga dituntut untuk menyatakan, merumuskan oral activities . Jadi, disemua tahap pada model pembelajaran kooperatif tipe CORE dapat mengaktivkan siswa.Hal ini menunjukkan bahwa model pembelajaran kooperatif tipe CORE berpengaruh positif sehingga aktivitas siswa menjadi aktif pada pembelajaran materi kubus dan balok.

Motivasi belajar siswa dengan diterapkannya model pembelajaran kooperatif tipe CORE pada pembelajaran materi Kubus dan Balok diperoleh rata-rata jumlah skor total seluruh indikator motivasi belajar positif dan negatif sebesar 3,94 dengan kategori Tinggi. Adapun hasil perhitungan rata- rata motivasi belajar positif dan negatif siswa dapat dilihat di Tabel 1 .

Tabel 1. Angket Hasil Rata- rata Motivasi Belajar Siswa

\begin{tabular}{clcc}
\hline No. & \multicolumn{1}{c}{ Indikator Motivasi } & Rata-rata & Kategori \\
\hline 1 & Hasrat keinginan untuk berhasil belajar & 4,15 & Tinggi \\
2 & Dorongan dan kebutuhan untuk belajar & 3,7 & Tinggi \\
3 & Harapan cita-cita masa depan & 4 & Tinggi \\
4 & Penghargaan dalam belajar & 3,9 & Tinggi \\
& Total & $\mathbf{3 , 9 4}$ & Tinggi \\
\hline
\end{tabular}

Adapun untuk motivasi belajar siswa dilihat dari angket terdiri dari beberapa indikator yaitu; (1) hasrat dan keinginan berhasil; (2) dorongan dan kebutuhan dalam belajar; (3) harapan dan cita-cita masa depan; (4) penghargaan dalam belajar. Berdasarkan hasil perhitungan angket motivasi belajar bahwa keempat indikator tersebut berada pada kategori tinggi. Selain itu, jika dilihat dari motivasi belajar siswa terhadap setiap butir pernyataan, diperoleh rata-rata jumlah skor total seluruh indikator motivasi belajar diperoleh rata-rata skor total sebesar 3,94 dengan kriteria motivasi belajar siswa tinggi. Sehingga, dengan demikian dapat disimpulkan bahwa motivasi siswa pada materi kubus dan balok dengan model pembelajaran kooperatif tipe CORE adalah tinggi. Penerapan pembelajaran dengan model CORE dapat membuat motivasi siswa berada pada kategori tinggi pada tahap Connecting pada tahap ini siswa diminta untuk menghubungkan pengetahuan yang telah lalu dengan pelajaran yang akan datang pada tahap ini siswa memiliki hasrat dan keinginan untuk berhasil, kemudian tahap Organizing dengan pengetahuan yang telah mereka peroleh siswa diminta dalam kelompok untuk mengorganisasikan soal atau pengetahuan yang telah yang telah mereka peroleh tahap ini siswa mempunyai hasrat dan keinginan untuk berhasil belajar serta memiliki dorongan kebutuhan untuk belajar, kemudian pada tahap Reflecting pada tahap ini siswa diuji kembali pemahamannya pada tahap ini sangat dibutuhkan hasrat keinginan untuk berhasil belajar, dorongan dan kebutuhan untuk belajar, harapan dan cita- cita masa depan serta penghargaan dalam belajar, kemudian tahap akhir Extending pada tahap ini siswa harus memiliki dorongan dan kebutuhan untuk belajar serta hasrat keinginan untuk berhasil belajar. Hal ini menunjukkan bahwa motivasi belajar siswa tinggi dengan adanya proses pembelajaran menggunakan model pembelajaran kooperatif tipe CORE pada materi kubus dan balok. Hasil ini sejalan dengan penelitian yang dilakukan oleh Auliani (2018) yang menyimpulkan bahwa dengan diterapkannya model pembelajaran CORE dapat membuat siswa lebih aktif dalam kegiatan pembelajaran sehingga dapat menjadi faktor motivasi yang penting untuk mengembangkan kemampuan koneksi matematis siswa karena siswa ikut berpartisipasi secara aktif untuk memperoleh pengetahuan yang dipelajari. 


\section{KESIMPULAN DAN SARAN}

Berdasarkan penelitian yang dilakukan dan pembahasan secara umum dapat disimpulkan bahwa terdapat perbedaan kemampuan koneksi matematis siswa yang mengunakan model CORE dengan siswa yang mengunakan pembelajaran konvensional, Aktivitas siswa terhadap model pembelajaran kooperatif tipe CORE membuat siswa menjadi sangat aktif, motivasi belajar siswa tergolong tinggi ketika diterhadapkan model pembelajaran kooperatif tipe CORE. Penelitian ini memiliki banyak kekurangannya, maka dari itu penulis perlu masukan dan saran dari dosen-dosen dan tim jurnal secara langsung.

\section{UCAPAN TERIMA KASIH}

Penulis mengucapkan terima kasih kepada kedua orang tua saya Ayahanda Agustinus Pawan dan ibunda Rosalia Diani terima kasih atas kasih sayang yang telah kalian berikan atas dukungan kalian dan suport kalian sehingga jurnal ini dapat terselesaikan, dan saya mengucapkan terimaksih juga buat suami saya Aris Siswanto atas dukungan suami, serta motivasinya membuat saya semakin semangat menyelesaikan jurnal ini, terimakasih banyak. Terimaksih saya ucapkan kepada seluruh dosen pendidikan Matematika STKIP Singkawang, kepada Ketua STKIP Singkawang Drs. Andi Mursidi, M.Si. kepada kedua pembimbing saya yaitu ibu Rika Wahyuni,S.Si, S.Pd, M.Pd dan ibu Mariyam, S.Pd, M.Pd yang telah memberikan arahan dan bimbingan dalam penulisan artikel hasil penelitian ini.

\section{REFRENSI}

Abdurrahman,M.(2012).Anakberkesulitanbelajar:teori,diagnosis,danremediasinya.Jakarta:RinekaCipt a.

Agustianti, R., \& Amelia, R. (2018). ANALISIS KEMAMPUAN KONEKSI MATEMATIS SISWA DENGAN MENGGUNAKAN MODEL PEMBELAJARAN CORE (CONNECTING, ORGANIZING, REFLECTING, EXTENDING). JPMI (Jurnal Pembelajaran Matematika Inovatif), 1(1), 1-6.

Auliani, A., Karim, K., \& Amalia, R. (2018) Pengaruh Model Pembelajaran Core Terhadap Kemampuan Koneksi Matematis Siswa SMP Kelas VIII.

Dewi,N.R.(2013).PeningkatanKemampuanKoneksiMatematis MahasiswaMelaluiBrainBasedLearning Berbantuan Web.Makalah Pendamping:PendidikanMatematika, 4(1).

Jacob,C.(2005).Pengembangan ModelCOREdalamPembelajaran Logika denganPendekatan ReciprocalTeachingbagiSiswaSMA Negeri9Bandung danSMANegeril Lembang.Bandung:LaporanPiloting FPMIPAUPI.tidak diterbitkan.

Khaulah, S. (2019). PENERAPAN MODEL PEMBELAJARAN CORE (CONNECTING, ORGANIZING, REFLECTING, EXTENDING) TERHADAP PENINGKATAN KEMAMPUAN KONEKSI MATEMATIKA SISWA PADA MATERI MATRIKS DI KELAS XI SMA NEGERI 3 BIREUEN. Jurnal Pendidikan Almuslim, 7(1).

Mandur,K., $\quad$ Sadra,I.W.,\&Suparta, I.N.(2013).KontribusiKemampuanKoneksi, KemampuanRepresentasi,danDisposisiMatematisterhadapPrestasiBelajarMatematika SiswaSMA SwastadiKabupatenManggarai.E-JournalProgramPascasarjana UniversitasPendidikan Ganesha ProgramStudi Pendidikan Dasar, 2.

Nurainah, N., Maryanasari, R., \& Nurfauziah, P. (2018). Analisis Kesulitan Kemampuan Koneksi Matematis Siwa Smp Kelas Viii Pada Materi Bangun Datar. JPMI (Jurnal Pembelajaran Matematika Inovatif), 1(1), 61-68.

NationalCouncil of Teacher Mathematics. (2000). Principles and Standars for School Mathematics. [Online]. Tersedia: www.nctm.org [10 April 2011]jurnal hal 5 
Nari,N.,\&Musfika,A.P.(2017).AnalisisKesulitanBelajarDitinjauDariKemampuan KoneksiMatematikaPesertaDidik.Procceding Iain, 1(2), 311-320. Batusangkar.

Ruspiani.(2000). Kemampuan SiswaDalam Melakukan Koneksi Matematika.Artikel UPI Bandung: Tidak diterbitkan. hal:46

Rokhaeni, A., Herman, T., \& Hidayat, A. S. (2011). Penerapan Model CORE Dalam Pembelajaran Matematika Untuk Meningkatkan Kemampuan Koneksi Matematis Siswa. Tersedia: https://www. academia. edu/5684094.[18 Meret 2016].

2015.Penerapan Model Core Dalam Pembelajaran Matematika Untuk Meningkatkan Kemampuan Koneksi Matematis Siswa. Bandung

Sugiman, S. (2008). Koneksi matematik dalam pembelajaran matematika di sekolah menengah pertama. Pythagoras: Jurnal Pendidikan Matematika, 4(1).

Septiati,E. (2012).KeefektifanPendekatanKontruktivismeTerhadapKemampuanKoneksi Matematis MahasiswaPadaMataKuliah AnalisisReal.In Prossiding SeminarNasional Matematika danPendidikan MatematikaFMIPAUNY, (Vol. 10). Yogyakarta

Sholekah,L.M.A.,\&Waluyo,A.(2017). Analisis Kesulitan Siswa Dalam Menyelesaikan Soal Matematika Ditinjau Dari Koneksi MatematisMateri Limit Fungsi. WACANA AKADEMIKA: Majalah Ilmiah Kependidikan, 1(2).

Saputra, A. N. N., Said, H. B., \& Defitriani, E. (2019). PERBANDINGAN KEMAMPUAN KONEKSI MATEMATIS SISWA MELALUI MODEL PEMBELAJARAN CONECTING ORGANIZING REFLECTING EXTENDING (CORE) DENGAN MODEL PEMBELAJARAN KONVENSIONAL DI KELAS VIII SMP NEGERI 15 KOTA JAMBI. PHI: Jurnal Pendidikan Matematika, 4(1), 304-308.

Sardiman, A.M. (2016). Interaksi dan Motivasi Belajar Mengajar. Jakarta : Raja Grafindo hal:96

Sugiyono. (2017). Metode Penelitian Kualitatif Kuantitatif dan $R \& D$. Bandung: ALFABETA hal:79

Siregar, Syofian. (2013). Metode Penelitian Kuantitatif Dilengkapi Perbandingan Perhitungan Manual \&SPSS. Jakarta: PRENADA MEDIA GROUP.

Wahyuningsih, N. (2017). PENINGKATAN KEMANDIRIAN BELAJAR MATEMATIKA DAN KEMAMPUAN KONEKSI MATEMATIS DENGAN MODEL CORE PADA SISWA SMP. EKUIVALEN-Pendidikan Matematika, 30(2). 